\title{
The Efficacyofantiscabies Medicinetohealing Scabiesin Patient Who Received Personal Hygiene Education
}

\author{
Feny Tunjungsari ${ }^{1}$, Didik Tamtomo $^{2}$, Bhisma Murti², Yusrin Aulia ${ }^{3}$ \\ ${ }^{1}$ Department of Family Medicine and Occupation Medicine, Muhammadiyah University of \\ Malang, Kampus II UMM, J1. Bendungan Sutami No. 188A, Malang Telp (0341) 564455 \\ 23Department of Family Medicine, Sebelas Maret University of Surakarta \\ ${ }^{4}$ Education Staff of Medical Faculty, Muhammadiyah University of Malang \\ Email : feny.tunjungsari@gmail.com \\ Received : Oct $10^{\text {th }}$ 2019. Revised : Oct 14th 2019 . Published : Dec $28^{\text {th }} 2019$ \\ DOI : https://doi.org/10.22219/sm.Vol15.SMUMM2.10559
}

\begin{abstract}
The prevalence of the scabies disease in a populated area (e.g islamic boarding schools) is still high .It is possible that disease skabies are still found here because the higiene individuals from the community. Skabies disease is easily treated, but to progress, the disease remains a big problem in the specific community health. This study attempts to analyze the effectiveness of an anti skabies permethrine comparedgameksanto healing patients who has been getting an individuals higiene education. Samples were 40 student the Islamic boarding in the malang district the age range of 12 - 18 years taken by random. The dependent variable was cure from scabies. The independent variable included anti-scabies (Gamexan and Permethrine). The sample taken as random. Research will be tested using chi-square to analized the data. The experimental work on chi square statistically from the analysis does not obtain a significant relation $(p=1,000)$ between the provision of treatment antiscabies gameksan and permethrine with healing on the subjects of research get education higiene individuals. Although statistically no meaning, but can be concluded that clinically better to use gameksan and permethrine, if the subject of study get education nice about education higiene individuals, there is no different effect between the provision of gameksan with permethrine.
\end{abstract}

Keyword : gameksan, permetrine, individuals hygiene education, healing.

Copyright (C) 2019, First Author et al This is an open access article under the CC-BY-SA license

\section{INTRODUCTION}

Skabies is skin eruption caused infestation and sensitization by parasites sarcoptes scabiei var. Hominis. A manifestation of clinical skabies can be lesions papular, pustular, vesicles, erosion to krusta, and tunnel epidermal colored gray. Complaints subjective of the of itching great at night. In people with children, the itching this great trigger sleep disorders. The itching especially felt in regions a gap or the body folds. Besides patients, there is usually others with complaints same around patients (Fitzpatrick, 2008., Azizah, I., 2011., Arlian, L., 2016). Skabies has been known for 
long time, when bonomo and cestoni capable of illustrate a mites as the cause of skabies in the 1689 (Montesu, 1991). The literature of stated that skabies be researched first by aristotle and cicero about three thousand years ago and so called as "lice in the flesh" (Alexander, 1984).

Skabies can be treated by giving therapy topical on the skin.Treatment topical recommended for the treatment skabies among others of lindane 0,3-1\%, lotio benzyl benzoic 10 to $25 \%$, cream permetrin 5 percent, esdepallethrine (aerosol), sulphur 2 and $10 \%$, sulfiram $25 \%$, and krotamiton $10 \%$.In indonesia preparation a topical drug most are many are the people of of lindane (example: scabicid) and permetrin (example : scabimite). Permetrin seen as a drug that effective but higher than other preparation. Skabies is relatively easy treated but it has since built a is still a health problems to specific groups (Arlian, L., 2016., Currie, B. 2015., Kouotou, E., 2016). According to the department of health of the republic of indonesia, is a disease of the skin skabies number 3 with the highest proportion in puskesmas indonesia as a whole with prevalence in 2008 about $5.6 \%$-- $12.95 \%$. Prevalence of penyakt skabies 2008 in different localities slums ( tpa, flat, in islamic boarding schools in semarang reached 5,80\%.Data of morbidity of \$skabies in 2008 the puskesmas level across the city of semarang is 1100 cases with $14,72 \%$ of them happened in toddlers (Azizah, I., 2011). Menurut riset di atas bukan tidak mungkin penyakit skabies masih banyak dijumpai dikarenakan faktor personal higiene dari masyarakat. Penulis ingin mengetahui apakah terdapat perbedaan efektifitas obat anti skabies Gameksan dan Permethrine pada pasien yang mendapat pendidikan higiene perorangan.

\section{Etiology Scabies}

Including the phylum arthopoda, sarcoptes scabiei the class arachnida, the order ackarina, a superfamily sarcoptes.A parasite that attacks on humans called sarcoptes scabiei var. Hominis. In a morphological, is small mites an oval shape, his back convex and the stomach average.It is transparent, mites dirty, and no. eyed The size of females ranges from 330 - 450 micron x 250 350, micron while the male smaller, namely 200 - 240 micron x $150-200$ micron. Adult form have 4 pairs of legs, 2 pairs of legs at the instrument instrument for attached to and 2 pairs of legs second in female ended with hair, while in males pairs of legs third ended with hair and fourth ended with a adhesive (Arlian, L., 2016., Grandholm, J.M., 2005).
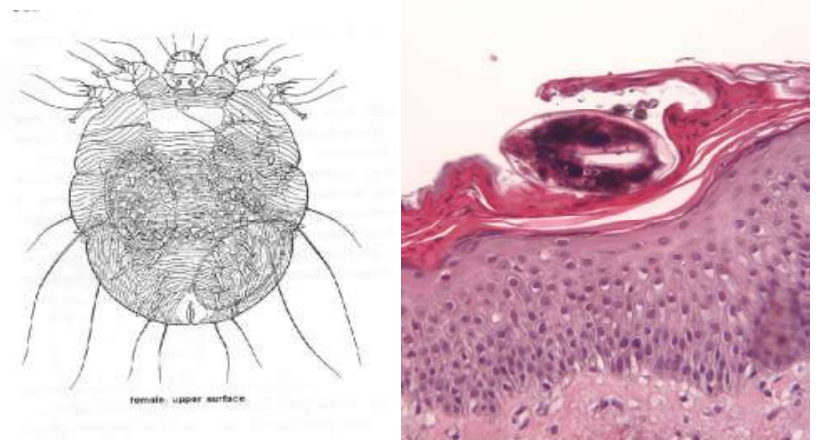

Picture 1. Skabies female and skabies pierce the skin tissue outside (Grandholm, J.M., 2005) 


\section{Patofisiology of Scabies}

This mites is parasitic obligate all its life cycle happened to the human body. Only mites the enter into the lining of human skin. The process maturation last for 15 days, with the form of the whose larvae akam appear 2 to 3 days after eggs laid. About 5 to 15 mites females can live in the human body, but in a short time can be hundreds of or even millions of in the case crusted scabies .Eruption of skabies because infestation of mites and also the process hypersensitivity to mites. The incubation period is complete before felt symptoms appear between three to six weeks in infestation primary, but can occur more rapidly between one to three days in the case reinfestasi (Arlian, L. 2016., Kouotou, E. 2016., Chosidow, O. 2006).

Skin disorder can be caused not only by mites skabies, but also due to a scratching post. own patients Shake hands or hand in so there a strong skin contact can cause skin lesions arising on the wrist.Itchy happened caused by sensitization against sekret and ekskret mites that take a month after. kira-kira infestationAt the time skin disorder resembling dermatitis with the invention of papule, a vesicle, urtica, and lain-lain. With a scratching post may arise, erosion ekskoriasi, nothing but crusting, and secondary infections. Itching and skin disorder occurs can be found far from the location of mites (Fitzpatrick, 2008., Grandholm, J.M, 2005).

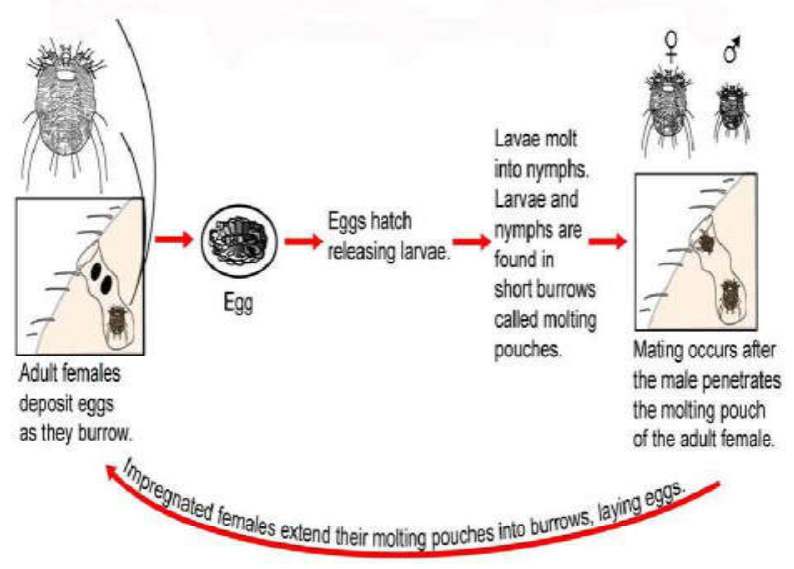

Picture 2. The life cycle parasites Sarcobtes scabiei

\section{Pathway}

This is parasitic mites obligate whose entire its life cycle is going on in the human body. Only the female mites that goes into a human skin.The process of maturation 15, lasted for days with the form of larvae that will show up 2 until 3 days after the eggs laid. About 5 until 15 female mite can live in the human body, but in no time can be hundreds of millions in the case crusted scabies.Eruption of skabies because infestation of the mites and also the process hypersensitivity to. mites The incubation period before it gets symptoms appear between three to six weeks on infestation, primary but it can happen more quickly between one and three days in the case reinfestasi (Arlian, L., 2016, Kouotou, E., 2016, Chosidow, O. 2006). 
Skin disorder can be caused not only by mites skabies, but also due to a scratching post. Own patientsshake hands or hand in so there a strong skin contact can cause skin lesions arising on the wrist.itchy happened caused by sensitization against sekret and ekskret mites that take a month after. Kira-kira infestationat the time skin disorder resembling dermatitis with the invention of a papule, a vesicle, urtica, and others.with a scratching post may arise, erosion ekskoriasi, nothing but crusting, and secondary infections.itching and skin disorder occurs can be found far from the location of mites (Fitzpatrick, 2008., Grandholm, J.M., 2005).

\section{Symptom of Scabies}

a. Pruritus okturna, this means that the itch in night because the mites are higher at a temperature that more humid and heat.

b. This disease attack humans in the group, for example in a family usually the whole family has an infection. So did in a cubical, densely populated area as well as life on, in boarding school most of the neighbors adjacent will be attacked by the mites. The state of hiposensitisasi, known that all members of his family exposed to, but did not give symptoms of. Patients with this is as a bearer (carrier).

c. The tunnel (kunikulus) predileksi in places that looks, grayish white in the form of a straight line or snaked, the average length of one $\mathrm{cm}$, at the end of the tunnel found papule. or vesicle Should there be a secondary infection of the skin rash polimorf (pustul, ekskoriasi, and others). The predileksinya usually a place with the stratum corneum, thin namely the sidelines, fingers the wrist, the elbow the outside, fold the armpit, the front aerola mame, woman, umbilicus, buttocks external genetalia, man and lower abdomen. In infants it can strike the palms and soles.

d. Find mites, was the most diagnostic can be found one or more stadium mites this life.

e. A symptom of shown is a red color, and intense itching irritation on the skin that is generally appear finger stated, the elbow, groin and a crease the thigh, and appearing bubbles watery on the skin .

\section{Diagnosys}

Some of these intractable disorders the skin resembling a dermatitis of, with or accompanied papules, vesicles, urtica, and lain-lain. Garukan a hand can springs from a sense of erosion, ekskoriasi, krusta, and secondary infection. In the tropics, almost each case of skabies infected secondary by streptococcus aureus or of staphylococcus pyogenes the diagnosis prepared and set up on the basis of the : (1). The existence of a tunnel that goes under a little risen waters, shaped a straight line or kelok-kelok, answerable to the length of some the millimeter until 1 police post $\mathrm{cm}$ grand cinema, and just at the head end there seems to be a vesicles, papules, or pustules. (2). A distinctive predileksi place is the sidelines of a finger, the wrist part volar, the elbow the outside of, fold the armpit the front, mammæ aerola to provide for them, the umbilicus, buttocks, the external genitalia guys. In adults exist in face and head, except in people with 
immunosuppressive, while on the baby, lesions can occur all over the surface of the skin. (3). Healing soon after administering a sedative topical antiskabies necessary to ensure that effective. (4). The great itching at night if more than one family member suffer, itching to be suspected of skabies. On the night of the itching caused by the body temperature to higher activity so the increase (Fitzpatrick, 2008, Chosidow, O. 2006).

The diagnosis skabies done by making kerokan the skin on regions that rosy color and itches. Kerokan carried out should be done somewhat in until the skin secreting blood because sarcoptes female live somewhat in in the skin by making the tunnel. To dissolve the crust of used solution koh $10 \%$ next the results of the kerokan observed with a microscope with a scaled up 1040. Time another way is to shed a immesi lesions, on oil and the epidermis at the top scraped off slowly.

\section{Management}

The treatment of skabies can be done with delousing namely shower with water that has been dissolved powder ddt (dichloro diphenyl trichloroetan). Another treatment is by smearing the ointment that has the miticid better than organic chemical substances and non-organik on piece of skin that feels itching and redness and settled for 10 hours. The alternative is washing with soap sulfur/sulphur because conceived for sulphur is an antiseptic and antiparasit, but the use of soap sulfur ca not be exaggerating because makes the skin dries up. The treatment of skabies should be conducted simultaneously to all individuals in the areas that had been skabies so as not contracting back by disease skabies.

The treatment of topical key ones of which are based on the recommendation of for the treatment of non skabies its industrial activity among others of lindane $0,3-1 \%$, lotio benzyl benzoic 10 - $25 \%$, cream permetrin $5 \%$, esdepallethrine (an aerosol), sulphur 2 - $10 \%$, sulfiram $25 \%$, and krotamiton $10 \%$. Yet at the same time that it has been used ddt is no longer based on the recommendation of. To the inflation rate although is still debatable permetrin is the cure the most effective. Permetrin $\mathrm{mmr}$ is not available for many areas of and is the cure skabies the most expensive one (Fitzpatrick, 2008., WHO. 2005).

Skabies can be treated by giving therapy lotio or cream on the skin .Treatment recommended for skabies is cream permetrin $5 \%$. Permethrin $5 \%$ cream has recognized as skabies therapy for patients the age 3 months or more by the food and drug administration (the fda) in 1989 (Hamm H, 2005., Currie BJ, 2010). While in the netherlands and england in 1991 (Hamm H,. 2005). Permethrin impairs its functions voltage-gated sodium channels of arthropods, causing lengthening depolarisasi nerve cell membranes and disturbing neurotransmisi (Zlotkin E. 1999) so parasitic would have paralysis and die (Usha V, 2000). In humans, from doses applied less than $2 \%$ absorbed through the skin, and a small part of the dose be metabolized quickly by including esterase network that is in epidermis. Inaktif products will excreted in the urine (Taplin D, 1990). 
The way the use of cream permetrin more or less as follows : smeared on the skin that is already clean in a sparse manner in all parts of the body from the neck to feet) then left to for at least 8 hours. After 8 hours, cream to be cleaned up with a shower. When applied on the skin, treatment around $90 \%$ effective after once the provision of, however pengolesan a second for the skin important to do on 7 to 10 days later. If therapy with permethin successfully, so the itching and redness slowly will been missing for 2 to 3 weeks. Symptoms may deteriorate in 1 to 2 days therapy, due to the emergence of an allergen of mite that dead. If signs and symptoms have progressed or have worsened, or if it appears lesions just starting out for seven to 14 days, it would probably will have (Fitzpatrick, 2008., Currie, B. 2015., Departemen Of Public Health. 2008). Based on the recommendation of to repeat this application is reasonable enough permethrin name if there is no repairing lesions or discovered a sign of reinfestasi, 1 on sunday and then (Albakri, 2010) or 2 weeks later (Usha V, 2000).

Therapy topical including benzyl benzoate (not available in america). Krotamiton and On trial in randomized trial conducted in vanuatu, where skabies is a major public health, rerata healing is in three weeks show $51 \%$ ( 19 of 37 patien) with $10 \%$ benzil benzoate, like averate healing $56 \%$ with $200 \mu \mathrm{g} / \mathrm{kg}$-weight. However, $3 \%$ of patients were teraphied reported benzil benzoate had burning or stinging, than $7 \%$ with oral diterapi ivermectin.In france, where permethrin not available, benzil benzoate therapy first line is topical, based on the experience of the experts.A review of the review cochrane concluded lack of data to compare benzil benzoate or effectiveness of lindane crotamiton with or permethrin. Data obtained from acak trial shows that efficacy crotamiton lower than permethrin in four weeks (61\% vs 89\%) (Chosidow, O. 2006).

Ivermectin monoterapi in reducing prevalence skabies after single, therapy an infection that is almost lost in komplet after 2. therapy or moreFor example, on the island of solomon skabies prevalence of 25 percent to $1 \%$ during treatment with. ivermectinIvermectin used for both onchocercosis in africa (Currie, B. 2015., Mohammed,et al. 2012).

Gameksan $1 \%$ were an option because it is effective against all stadium, lice easy to use, and rarely cause skin irritation.But medicine is not recommended for pregnant women, and child under age 6, years because nature are toxic to the arrangement of the nerves. centralPemakaiannya enough once. smeared all over the bodyMay be repeated one week if not recover (Depatemen Kesehatan R.I. 2007., Georgia Departement of Public Health. 2012).

\section{Personal Hygiene Education}

Clean and healthy lifestyle (healthy life) are the paradigm living a healthy in individual culture, the household and healthy, oriented for the purpose of raising, nurture and protect either physical, health mental spiritual and socially (Azizah, I., 2011).

One of indicators Clean and healthy lifestyle in order households are cleanliness ad individual personal hygiene. A person is said to personal hygiene-nya good if the candidate can 
maintain cleanliness of his body which covering cleanliness the skin, nails, hair, the mouth and teeth , clothing, eyes, the nose, and ears, and cleanliness genitals. Higiene individual is a the act of to maintain cleanliness and health of a person for the welfare of physical and psychological. Higiene individual aimed at so that people can defend health yourself, heightens and fix the value of health, and prevent the disease. Higiene individual here include cleanliness the skin, cleanliness hair, dental and mouth, cleanliness hand, care toenails and hand, discharging footwear, cleanliness clothing, food and shelter (Azizah, I., 2011).

Higiene individuals more influenced by a factor of value and the practice of individuals .Another factor is cultural factors, social, the family, and the factors individual factors such as knowledge on health, and the perception of the needs and safe individual level adjustments (Kouotou, E., 2016., Badri, M. 2007). Modification higiene individuals in the treatment of skabies is the suggestion of all so as his, an instrument sleep, and the towel, have to water soaked hotter before washed and dried with hot air (Fitzpatrick, 2008).

\section{MATERIAL AND METHODE}

Research plans kabupaten malang carried out in areas. Research design used design experimental research. Target population: the pesantren in kabupaten malang - 12 with the age range of 18 years. Population of poor pesantren: in the kabupaten the sample random sample taken by and large estimated by large multivariate formula samples for analysis, required 15 to 20 samples for one variable independent, see because there are two independent variable it takes 30 to 40 sample.

To know the influence of drugs anti scabies of healing scabies in patients who have education higiene individuals measured by chi- square 


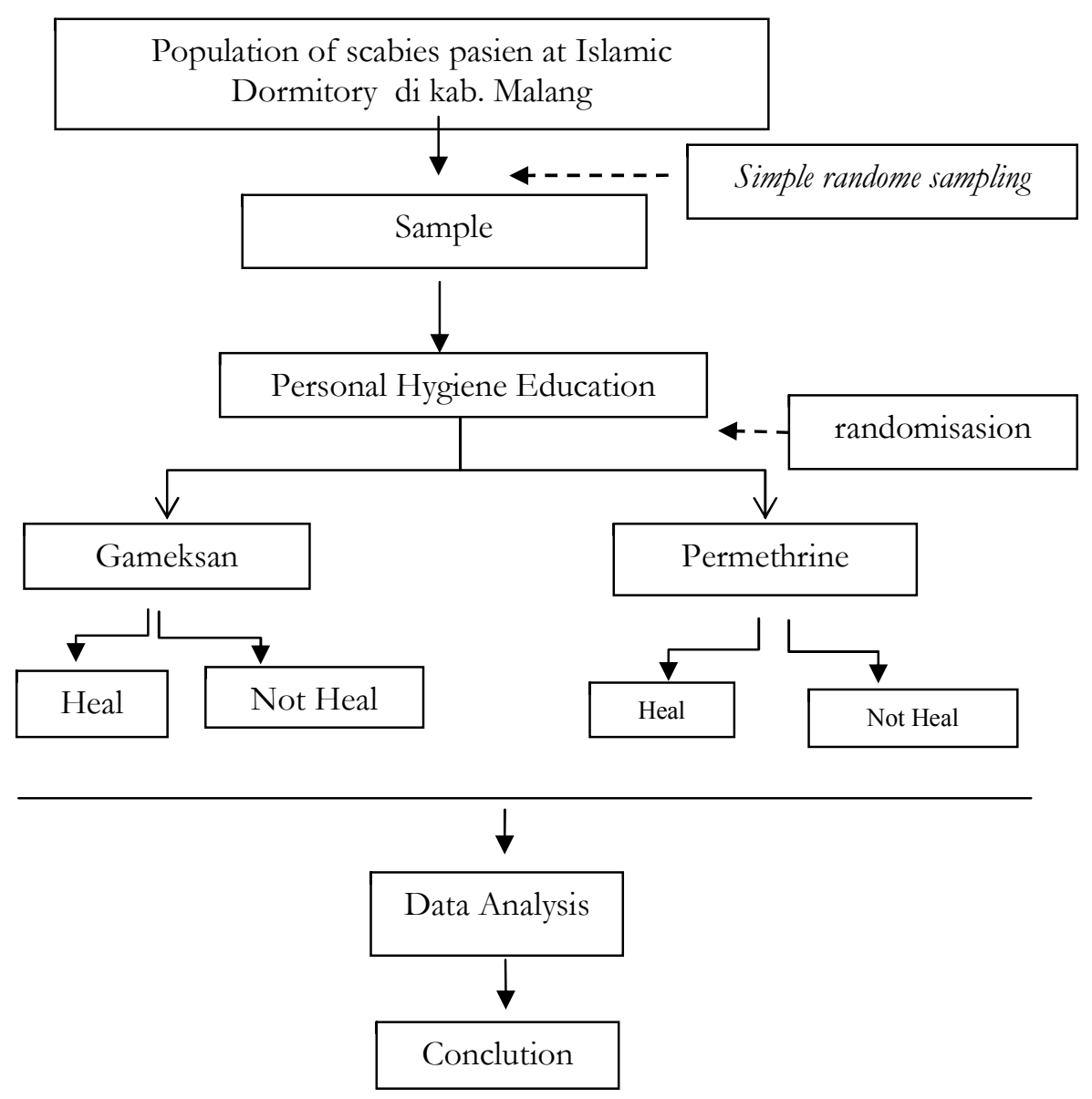

Flowchart 1. The scheme of research design

\section{RESULT}

Data of Variable Samples Research

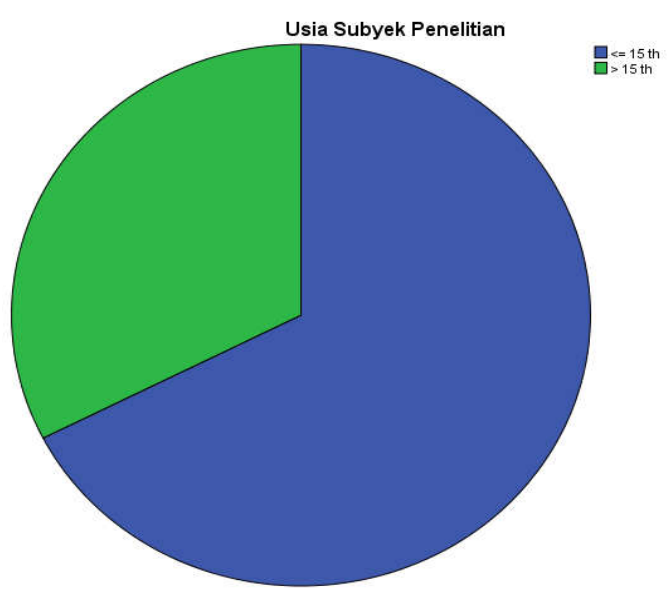

Diagram 1. Age of Research's Subject

The Diagram show amount age of subject in $\leq 15$ years old is 27 people $(67,5 \%)$, while age of subject $>15$ years old is 13 orang $(32,5 \%)$. 


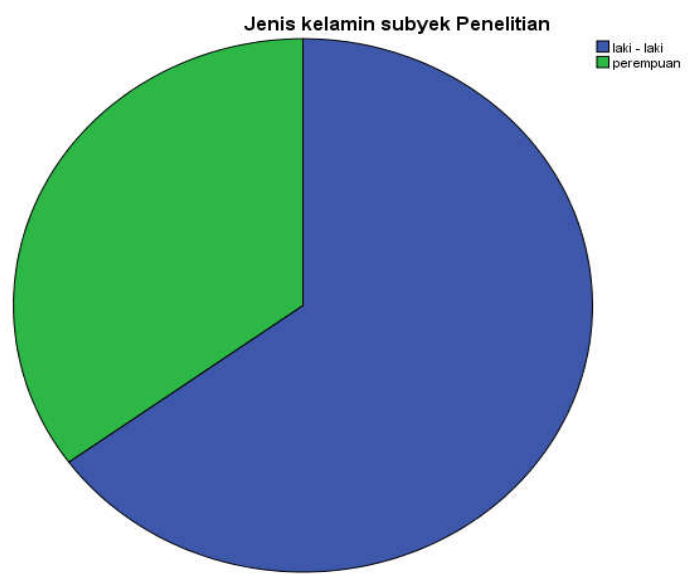

Diagram 2. Sex of Research subject

The diagram shows the amount of male is 26 people $(65 \%)$, While the amount if female is 14 people $(35 \%)$.

Table 1. The results of the bivariat analysis to the chi square with administering medication anti skabies with healing

\begin{tabular}{lcccc}
\hline \multirow{2}{*}{ Group } & \multicolumn{3}{c}{ Healing } & \multirow{2}{*}{ p } \\
\cline { 2 - 4 } & Yes $(\%)$ & No $(\%)$ & Total & 1,000 \\
Permethrin & $17(42,5 \%)$ & $3(7,5 \%)$ & $20(50 \%)$ & \\
Gameksan & $16(40 \%)$ & $4(10 \%)$ & $20(50 \%)$ & \\
Total & $33(82,5 \%)$ & $7(17,5 \%)$ & $40(100 \%)$ & \\
\hline
\end{tabular}

Table analysis bivariat relations the type of medication with healing, show from sample 20 get permetrin therapy, a number of 17 ( $42,5 \%)$ healed and 3 the $(7,5 \%)$ not healed. While of those 20 samples who have gameksan therapy a number of 16 ( $40 \%)$, healed and the $4(10 \%)$, not healed with $\mathrm{p}$ value $=1,000$.

On the outcome of the above analysis known that there is no significant difference between the gameksan with permetthrine in patients who have received personal higiene education. According to previous studies stated that users permethrine more effective than lindane (gameksan ) in skabies medication (Zargari, O., et all. 2016). There is a possibility that because they the studies have getting an education about higiene personal financial resources. This is in accordance with the research by sholilah in the year 2015 which states that a significant relation exists between the education by building the incident when the town skabies, a person with a good education just a little the proportion who experienced skabies (Sholilah, 2015). Research conducted by sianturi in a Islamic dormitory $\mathrm{x}$ in east jakarta concluded that personal cleanliness relating to skabies, students who have personal cleanliness is small in skabies, this is different to students who have poor personal cleanliness more in skabies (Sianturi, 2014). 


\section{CONCLUTION AND SUGGESTION}

In research statistically by analysis chi square does not obtain a significant relation $(\mathrm{p}=$ $1,000)$ between the treatment and antiskabies gameksan permethrine with healing on the subjects of research higiene individual get education.Statistically, although no meaning but can be inferred that better to use and clinically gameksan permethrine, if the subject of study get education nice about individual higiene, education there is no different effect between the gameksan with permethrine.

The research results can be used as a reference to health workers strata first to menerapi patients didioagnosis skabies, especially a patient who lives in boarding schools where boarding schools is one place that still a lot of skabies. found the rate of not only just, in therapy it turns out education higiene individuals it turns out to the patient must also diedukasikan.Is expected to educate patients about education higiene individuals to the patient, going to happen, change of attitude so that patients mererapkan higiene individuals with good and right.

Based on the research done then the researcher suggested the existence of an active role of the local chamber of in islamic boarding schools in the region of kabupaten malang to be always made it a prestige issue a pattern higiene personal financial source good and advantageous things to students santri to weed out frivolous candidacies. So that sickness skabies which so far has been there are always in islamic boarding schools could be reduced their distribution.

\section{REFERENCES}

Albakri, 2010

Alexander, 1984

Arlian, L., Marjorie, M., 2016. Sarcoptes scabiei: genomics to proteomics to biology. Parasites Vectors. 9:380

Azizah, I., Setiyowati, W., 2011. Hubungan Tingkat Pengetahuan Ibu Pemulung Tentang Personal Hygiene dengan Kejadian Skabies pada Balita di Tempat Pembuangan Akhir Kota Semarang. Dinamika Kebidanan. Vol. 1

Badri, M. 2007. Hygiene Perseorangan Santri Pondok Pesantren Wali Songo Ngabar Ponorogo. Media Litbang Kesehatan. Vol XVII

Chosidow, O. 2006. Scabies, Clinical Practice. N Eng J Med. 354:16

Currie BJ, McCarthy JS. 2010. Permethrin and Ivermectin for Scabies. N Engl J Med. 362:717-25.

Currie, B. 2015. Scabies and Global Control of Neglected Tropical Diseases. N Eng J Med. 373:24

Departemen Of Public Health. 2008. Scabies. Vector-Borne Disease Section, 1616 Capitol Ave, MS 7307, Sacramento, CA 95899-7413.

Depatemen Kesehatan R.I. 2007. Skabies. Pedoman Pengobatan Dasar di Puskesmas 2007. 208210.

Fitzpatrick, 2008

Georgia Departement of Public Health. 2012. Scabies Handbook. 
Grandholm, J.M ; Olszeweki, J. 2005. Scabies Prevention and Control Manual. Michigan Departement of Community Health

Hamm H, Beiteke U, Hoger PH, Seitz CS, Thaci D, Sunderkotter C. 2005. Treatment of scabies with 5\% permethrin cream: results of a German multicenter study. JDDG. 5: 407-13

Kouotou, E. Nanseu J., Kouawa, M., 2016. Prevalence and drivers of human scabies among children and adolescents living and studying in Cameroonian boarding schools. Parasites Vectors. 9:400

Mohammed,et al. 2012. Soil transmitted helminths and scabies in Zanzibar, Tanzania following mass drug administration for lymphatic filariasis - A Scabies and Global Control of Neglected Tropical Diseases : Rapid Assessment Methodology to Assess Impact. Parasites Vectors. 5:299

Montesu, 1991

Sholilah, 2015

Sianturi, 2014

Taplin D, Meinking TL, Chen JA, Sanchez R. 1990. Comparison of Crotamiton 10\% cream (Eurax) and Permethrin 5\% cream (Elimite) for the treatment of scabies in children. Pediatry Dermatol. 7: 67-73.

Usha V, Nair TVG. 2000. A comparative study of oral ivermectin and topical permethrin cream in the treatment of scabies. J Am Acad Dermatol. 2000; 42: 236-40.

WHO. 2005. Epidemiology and Management of Common Skin Diseases in Children in Developing Countries, p28

Zargari, O., et all. 2016. Comparison of The Efficacy of Topical 1\% Lindane vs 5\% Permethrine in scbies: A randomized, double- blind study. Indian Journal Dermatology Venerology Leprology

Zlotkin E. 1999. The insect voltage-gated sodium channel as target of insecticides. Annu Rev Entomol. 44: 429-55. 